\title{
Spatial distribution of trace elements in surface sediments of Hooghly (Ganges) river estuary in West Bengal, India
}

\author{
Marco Trifuoggi ${ }^{1}$ - Luciano Ferrara ${ }^{1} \cdot$ Maria Toscanesi $^{1}$ - Priyanka Mondal ${ }^{2} \cdot$ Jonathan Muthuswamy Ponniah $^{3}$. \\ Santosh Kumar Sarkar ${ }^{2} \cdot$ Michele Arienzo $^{4}$ (I)
}

Received: 6 April 2021 / Accepted: 7 August 2021 / Published online: 31 August 2021

(C) The Author(s) 2021

\begin{abstract}
The spatial distribution of trace elements in surface sediments of the Hooghly estuary was studied over the monsoons in 2014 2017. As, $\mathrm{Cd}, \mathrm{Ni}, \mathrm{Pb}$ and $\mathrm{U}$ were two- to sixteen-fold the crust means with increasing levels toward the estuary, with Ni peak during the post-monsoon. Pearson's correlation matrix, cluster analysis, enrichment factors and pollution index revealed the anthropic source and association of trace elements with $\mathrm{Fe}, \mathrm{Mn}$ and $\mathrm{Al}$ and of $\mathrm{Pb}$ with $\mathrm{U}$. Geoaccumulation index revealed for $\mathrm{Ni}$ an extremely contaminated situation at the estuary water during monsoon and for $\mathrm{Cd}$ a heavily contaminated situation at freshwater location. The potential contamination index was $>6$; thus, sediments were very severely contaminated by As, Cd and $\mathrm{Ni}$ with worst situation for $\mathrm{As}$ and $\mathrm{Cd}$ at fresh and brackish water and during post-monsoon. The overall ecological risk was severe, $300 \leq \mathrm{RI}<600$ at all sites and seasons, especially after the monsoon, at fluvial and brackish locations.
\end{abstract}

Keywords Hooghly estuary $\cdot$ Trace elements $\cdot$ Sediment pollution $\cdot$ Multivariate analysis $\cdot$ Pollution index factors $\cdot$ Ecological risk assessment

\section{Introduction}

Trace elements, TEs, concentrations in sediments of fluvial and estuarine environments are affected by input coming from discharge of industrial and urban sewage or by atmospheric deposition in the catchment. The Ganges, locally called Ganga, is a large river on the Indian subcontinent that crosses the plains of northern India and Bangladesh. It has a length of

Responsible Editor: Xianliang Yi

Michele Arienzo

michele.arienzo@unina.it

1 Dipartimento di Scienze Chimiche, Università degli Studi di Napoli Federico II, Complesso Universitario di Monte Sant'Angelo, via Cintia 26, 80126 Naples, Italy

2 Department of Marine Science, University of Calcutta, 35 Ballygunge Circular Road, Calcutta 700019, India

3 Centro Interdisciplinario de Investigaciones y Estudios sobre Medio Ambiente y Desarrollo, Instituto Politécnico Nacional, Calle 30 de Junio de 1520, Barrio la Laguna Ticomán, C.P. 07340, Del. Gustavo A. Madero, Ciudad de México, Mexico

4 Dipartimento di Scienze della Terra, dell'Ambiente e delle Risorse, Università degli Studi di Napoli Federico II, Complesso Universitario di Monte Sant'Angelo, via Cintia 26, 80126 Naples, Italy
$2510 \mathrm{~km}$, and its sources are located on the Gangotri glacier in the Indian state of Uttarakhand in the central Himalayas. It flows into the Bay of Bengal with a large delta in the Sundarbans region. Together with its tributaries, it drains a catchment area that covers about one million $\mathrm{km}^{2}$, supporting one of the most densely populated regions of the planet Earth (Sarkar et al. 2017). Almost half of India's population lives in a third of the country's territory, within the Ganges Plain (Indo-Ganges). The river basin of Ganga and its estuary can be considered an ideal site for studying the influence of anthropic pressure on the flows of TEs. The Ganges splits into the Padma and the Hooghly River, HR, near Murshidabad district of West Bengal. The Padma flows eastward into Bangladesh, whereas the Hooghly flows south through West Bengal. The catchment area of HR and its estuary, HRE, are highly urbanized, with commercial, light industrial and domestic land use areas. Details of the main features of anthropic pressure on this estuary are reported by a report of state on environment of the West Bengal Pollution Control Board, WBPCB (2009), and by the Central Pollution Control Board, CPCB (2013). This latter survey reveals that in West Bengal, there is a large presence of chemical industries like petrochemical, fertilizer and textile plants and pulp paper mills beside hospital discharging huge volumes of untreated wastes 
into the river water. The literature reports several studies dealing with the level of pollution by TEs of HR sediments: Ghosh et al. (1983); Chakraborty and Gupta (2003); Dutta et al. (2005); Kar et al. (2008); Jonathan et al. (2010); Paul and Sinha (2013); Sarkar et al. (2017); Paul (2017); and Mondal et al. (2018a, 2018b, 2020).

One of the key environmental factors affecting the destiny of TEs especially in complex morphogeological context like the HR is represented by the climatic conditions: this area is dominated by a sub-tropical climate with cyclic successions of three distinct seasons, a pre-monsoon season extending from March to June, a monsoon season from July to October, and a post-monsoon season from November to February. The monsoon season is dominated by heavy precipitation, $\sim 70-80 \%$ of the total precipitation and with mean rainfall of $\sim 1700 \mathrm{~mm}$ (Rakshit et al. 2014). These intense raining events produce up to $\sim 3000 \pm 1000 \mathrm{~m}^{3} / \mathrm{s}$ of mixed volumes of water and sediment to be washed off from the land and then, in the subsequent seasons, i.e., pre-monsoon, decreases up to $\sim 1000 \pm 80 \mathrm{~m}^{3} / \mathrm{s}$ (Ray et al. 2015). This seasonal and intense variation of the climatic conditions adds to tide semidiurnal.

Thus, the high variation of the climatic conditions in a very short time span, typical of the monsoon season, greatly affects the composition and levels of TEs in sediments due to large introduction of terrigenous materials and mixing and transport effects on intertidal sediments and sudden changes of sea currents induced by monsoon winds and storms. The mean rate of sediment accumulation in HRE is elevated and ranges from 3.0 to $4.8 \mathrm{~mm} \mathrm{year}^{-1}$ (Banerjee et al. 2012). The massive input of sediments from anthropic pressure and natural events significantly affects TEs sediment binding. Another factor that influences the interaction of TEs with sediments is the salinity gradient. The consistent input of organic matter, clay and sulphide contents in the first tract of the river can increase TEs enrichment of intertidal sediments, whereas higher salinity conditions in the lower river stretch can decrease sorption (Du Laing et al. 2008). Some authors report, for instance, the chemical shifting of $\mathrm{Cd}(\mathrm{II})$ in solution from $\mathrm{Cd}^{2+}{ }_{\text {aq }}$ to $\mathrm{CdCl}^{+}, \mathrm{CdCl}_{2}, \mathrm{CdCl}_{3}{ }^{-}$and $\mathrm{CdCl}_{4}{ }^{2-}$ forms with increasing salinity (Battaglini et al. 1993; Helmke 1999). Besides the complexation action of anions, there is also another route through which salinity can alter TEs sorption and occurs when $\mathrm{Ca}^{2+}$ and $\mathrm{Mg}^{2+}$ compete for metals for sorption sites (Paalman et al. 1994) as is often the case of $\mathrm{Zn}$ and Cd (Millward and Liu 2003).

The current study, carried out over 2014-2017, determined the effect of the anthropic pressure and the water physical chemical features on TEs levels in three distinct specific areas of HRE over the monsoons: an upstream freshwater zone, a downstream brackish water zone and an estuarine saline water zone. For each year, season and zone, classical statistics, multivariate statistical analyses and pollution factor methods were applied, as well the environmental risk, the potential ecological risk, $E_{r}^{i}$, and comprehensive ecological hazard indices, RI.

\section{Materials and methods}

\section{Sampling sites}

Eight sites, namely, Tribeni, S1; Barrackpore, S2; Babughat, S3; Budge Budge, S4; Nurpur, S5; Diamond Harbour, S6; Lot 8, S7; and Gangasagar, S8 (Figure 1), were sampled over the seasons along the $\sim 175-\mathrm{km}$-long tidal stretch of the HRE from November 2014 to May 2017 for a total of 176 specimens. The chosen sites present different environmental conditions, where S1-S4 are fluvial sites with no tidal influence, S5-S6 show brackish water, while $\mathrm{S} 7-\mathrm{S} 8$ are typically estuarine stations. S8 is situated at the confluence of river Hooghly and Bay of Bengal, while $\mathrm{S} 1$ is in the upstream region.

\section{Collection and pre-treatment of sediments}

Water salinity was determined by conductivity and temperature measurement with a resolution of 0.01 psu according to the standard water analysis method (APAT-IRSA CNR 2003). Surface sediments were taken by a Van Veen grab and placed in plastic bags using plastic spatula in triplicate from the intertidal regions during ebb tide covering pre-monsoon, monsoon, and post-monsoon season (Arienzo et al. 2020a, b). Samples were kept in acid-rinsed polyethylene bags and temporarily stored in a cooler box with ice packs at $4^{\circ} \mathrm{C}$. The sediments were stored at $-20^{\circ} \mathrm{C}$ until further analyses. They were oven-dried at $80^{\circ} \mathrm{C}$ to constant weight and gently grounded and crushed (Trifuoggi et al. 2017; Sarkar et al. 2017; Mondal et al. 2018a).

\section{Analysis of sediments}

Dry sediment of $\leq 2 \mathrm{~mm}$ was analysed for $\mathrm{pH}$, organic carbon $\left(\mathrm{C}_{\text {org }}\right)$, carbonate, granulometric parameters and TEs, $\mathrm{Al}, \mathrm{As}$, $\mathrm{Cd}, \mathrm{Co}, \mathrm{Cr}, \mathrm{Cu}, \mathrm{Fe}, \mathrm{Hg}, \mathrm{Mn}, \mathrm{Ni}, \mathrm{Pb}, \mathrm{U}$ and $\mathrm{Zn}$ as described in previous works (Trifuoggi et al. 2017; Sarkar et al. 2017; Mondal et al. 2018a). For TEs, $\sim 0.5 \mathrm{~g}$ was digested with $10 \mathrm{ml}$ of a $\mathrm{HCl}-\mathrm{HNO}_{3}-\mathrm{H}_{2} \mathrm{O}_{2}$ mixture, $6: 3: 1$, and assisted by microwave (Mars-CEM, US). After cooling, the samples were filtered and taken to final volume of $50 \mathrm{ml}$ with ultrapure water. Mineralized samples were analysed by ICP-MS (Aurora M90 Bruker, USA) in triplicate. The detection limit, LOD, and limit of quantification, LOQ, were calculated using the method of blank variability for each investigated element. The calculated average values of LOD and LOQ were 0.06 and $0.16 \mu \mathrm{g} / \mathrm{kg}$, respectively. The accuracy, precision and recovery were evaluated using certified reference materials 
Fig. 1 Map showing the location of eight sampling sites (S1 to S8) along the Hooghly river estuary. The intricate river network and position of industries are also shown

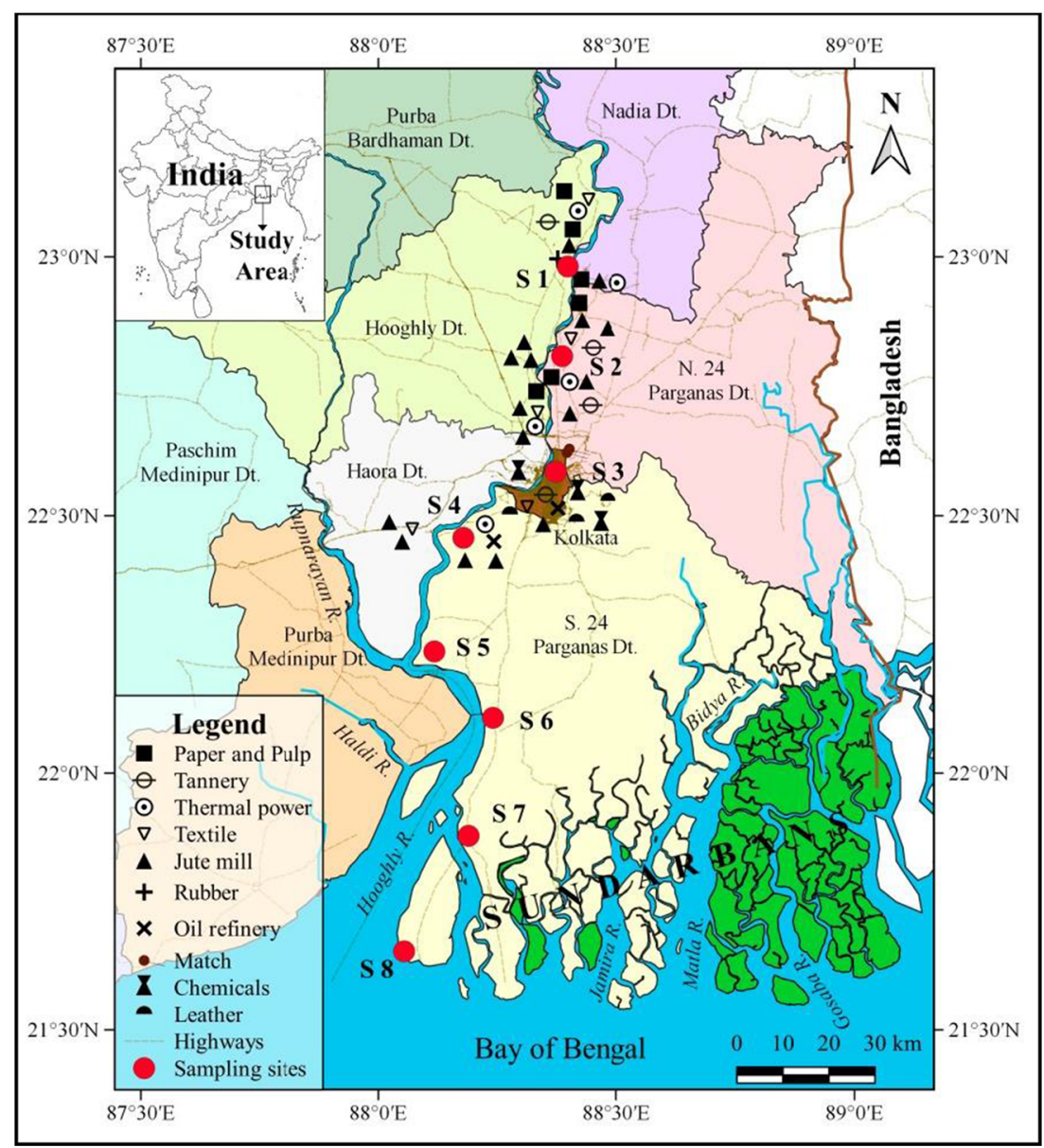

CR-CRM667, European Commission, Joint Research Centre, Belgium, and by participation to inter-laboratory circuits. The percentage recovery was $60-120 \%$ and the RSD, $n=3,2-$ $15 \%$. Statistical analysis consisted of skewness and kurtosis statistical tests (Zhang et al. 2009), Pearson's correlation matrix, a principal component analysis (PCA) and a hierarchical cluster analysis (HCA) and was performed by Statistica v.5 (StatSoft Inc., Tulsa, OK, USA).

\section{Results and discussion}

\section{Properties of sediments}

The geochemical characteristics of sediments are summarized in Table 1. Data are splitted for salinity area of the studied sites: the fluvial sites S1-S4 with a salinity of $0.13-0.3 \mathrm{psu}$, the brackish sites S5 and S6 with a salinity of 1.1-6.0 psu and the estuarine stations S7 and S8 with a salinity of 7.5-22.5 psu. Overall, the mean $\mathrm{pH}$ values of the brackish, 7.55-7.59, and estuary areas, 7.44-7.46, are slightly basic and higher than those of the freshwater location, 7.26-7.41, with maximum slightly basic peaks of 8.11 at $\mathrm{S} 5$ and minimum slightly acidic values at S3, 6.77, and S4, 6.85. Values reveal a certain increasing $\mathrm{pH}$ trend toward the outer part of the estuary due to marine influence. The $\mathrm{C}_{\text {org }}$, expressed as $\%$, fluctuated among the sediment samples with no regular distribution pattern. Very low content of $\mathrm{C}_{\text {org }}$ was observed in the intertidal sediments of HRE, with mean values of $0.34-0.51 \%$ in the fluvial area, $0.39-0.47 \%$ in the brackish area and $0.42-0.43 \%$ in the estuary. These values were lower than those found in sediments from other Indian coastal areas, such as Gulf of Mannar (Jonathan and Ram Mohan 2003), cochin (Sunil Kumar 1996) and Muthupet mangroves (Janaki-Raman et al. 2007), and match with those reported by Subba Rao (1960), reporting very low organic carbon values in the shelf sediments of the east coast of India (Krishna and Godavari basins) made of very fine grains of clay and silt. Peaks of $\mathrm{C}_{\mathrm{org}} \%$ were determined at S3, 1.14; S4, 0.75; and S6, 0.84. The lowest concentration of organic carbon in the outer stations is due to a large difference in environmental conditions regarding the rate of sediment deposition, tidal effects, microbial degradation (Antizar-Ladislao et al. 2015) and sediment sorption capacity for organic compounds (Sarkar et al. 2004; Chatterjee et al. 2007).

The content of $\mathrm{CaCO}_{3}$ was generally high and with a clear decreasing trend from the inner part of the estuary toward the open sea, with mean values varying from $12.46 \%$ at $\mathrm{S} 1$ to 
Table 1 Sampling location associated to mean values of salinity, $\mathrm{pH}, \mathrm{C}_{\mathrm{org}}, \mathrm{CaCO}_{3}$ and grain size of sediments from $\mathrm{HRE}$

\begin{tabular}{|c|c|c|c|c|c|c|c|c|c|c|}
\hline Zones & Sampling sites & $\begin{array}{l}\text { Latitude } \\
\mathrm{N}\end{array}$ & $\begin{array}{l}\text { Longitude } \\
\text { E }\end{array}$ & $\mathrm{pH}$ & $\mathrm{C}_{\text {org }}(\%)$ & $\mathrm{CaCO}_{3}(\%)$ & Sand $(\%)$ & Silt (\%) & Clay (\%) & Class* \\
\hline \multirow{4}{*}{$\begin{array}{l}\text { Freshwater } \\
\sim 90 \mathrm{~km}\end{array}$} & S1 Tribeni & $\begin{array}{r}22^{\circ} 59^{\prime} \\
25^{\prime \prime}\end{array}$ & $88^{\circ} 24^{\prime} 12^{\prime \prime}$ & $\begin{array}{l}7.27 \\
(6.93-7.90)\end{array}$ & $\begin{array}{l}0.34 \\
(0.15-0.72)\end{array}$ & $\begin{array}{l}12.46 \\
(9.09-15.60)\end{array}$ & $\begin{array}{l}19.49 \\
(11.22-32.08)\end{array}$ & $\begin{array}{l}30.80 \\
(8.94-50.6)\end{array}$ & $\begin{array}{l}49.71 \\
(36.91-75.72)\end{array}$ & Clay loam \\
\hline & S2 Barrackpore & $\begin{array}{r}22^{\circ} 45^{\prime} \\
51^{\prime \prime}\end{array}$ & $88^{\circ} 20^{\prime} 40^{\prime \prime}$ & $\begin{array}{l}7.41 \\
(7.05-7.73)\end{array}$ & $\begin{array}{l}0.42 \\
(0.24-0.63)\end{array}$ & $\begin{array}{l}13.43 \\
(10.04-16.33)\end{array}$ & $\begin{array}{l}15.84 \\
(2.34-30.06)\end{array}$ & $\begin{array}{l}35.19 \\
(17.15-62.18)\end{array}$ & $\begin{array}{l}48.97 \\
(14.89-70.54)\end{array}$ & Clay loam \\
\hline & S3 Babughat & $\begin{array}{r}22^{\circ} 49^{\prime} \\
32^{\prime \prime}\end{array}$ & $88^{\circ} 21^{\prime} 39^{\prime \prime}$ & $\begin{array}{l}7.39 \\
(6.77-7.76)\end{array}$ & $\begin{array}{l}0.51 \\
(0.15-1.14)\end{array}$ & $\begin{array}{l}11.48 \\
(4.4-14.69)\end{array}$ & $\begin{array}{l}16.78 \\
(3.35-28.89)\end{array}$ & $\begin{array}{l}34.96 \\
(23.23-55.43)\end{array}$ & $\begin{array}{l}48.52 \\
(35.42-64.09)\end{array}$ & Clay loam \\
\hline & $\begin{array}{l}\text { S4 Budge } \\
\text { Budge }\end{array}$ & $\begin{array}{r}22^{\circ} 33^{\prime} \\
58^{\prime \prime}\end{array}$ & $88^{\circ} 11^{\prime} 16^{\prime \prime}$ & $\begin{array}{l}7.26 \\
(6.85-7.53\end{array}$ & $\begin{array}{l}0.51 \\
(0.18-0.75)\end{array}$ & $\begin{array}{l}11.4 \\
(8.33-13.43)\end{array}$ & $\begin{array}{l}14.96 \\
(4.96-22.33)\end{array}$ & $\begin{array}{l}33.43 \\
(23.7-62.33)\end{array}$ & $\begin{array}{l}51.60 \\
(29.79-71.34)\end{array}$ & Clay loam \\
\hline \multirow[t]{2}{*}{$\begin{array}{l}\text { Brackish } \\
\sim 23 \mathrm{~km}\end{array}$} & S5 Nurpur & $\begin{array}{r}22^{\circ} 12^{\prime} \\
40^{\prime \prime}\end{array}$ & $88^{\circ} 04^{\prime} 16^{\prime \prime}$ & $\begin{array}{l}7.59 \\
(6.80-8.11)\end{array}$ & $\begin{array}{l}0.39 \\
(0.15-0.65)\end{array}$ & $\begin{array}{l}11.14 \\
(7.20-13.89)\end{array}$ & $\begin{array}{l}7.45 \\
(2.15-13.45)\end{array}$ & $\begin{array}{l}32.93 \\
(24.26-61.70)\end{array}$ & $\begin{array}{l}59.62 \\
(36.15-68.52)\end{array}$ & Clay loam \\
\hline & $\begin{array}{l}\text { S6 Diamond } \\
\text { Harbour }\end{array}$ & $\begin{array}{r}22^{\circ} 11^{\prime} \\
13^{\prime \prime}\end{array}$ & $88^{\circ} 11^{\prime} 24^{\prime \prime}$ & $\begin{array}{l}7.55 \\
(7.16-7.94)\end{array}$ & $\begin{array}{l}0.47 \\
(0.12-0.84)\end{array}$ & $\begin{array}{l}11.20 \\
(6.34-14.74)\end{array}$ & $\begin{array}{l}8.73 \\
(4.36-13.67)\end{array}$ & $\begin{array}{l}32.85 \\
(24.98-63.29)\end{array}$ & $\begin{array}{l}58.43 \\
(31.68-66.01)\end{array}$ & Clay loam \\
\hline \multirow[t]{2}{*}{$\begin{array}{l}\text { Estuarine } \\
\sim 63 \mathrm{~km}\end{array}$} & S7 Lot 8 & $\begin{array}{r}22^{\circ} 52^{\prime} \\
29^{\prime \prime}\end{array}$ & $88^{\circ} 10^{\prime} 09^{\prime \prime}$ & $\begin{array}{l}7.46 \\
(7.03-7.83)\end{array}$ & $\begin{array}{l}0.42 \\
(018-0.76)\end{array}$ & $\begin{array}{l}11.71 \\
(1.98-15.54)\end{array}$ & $\begin{array}{l}10.45 \\
(0.9-20.09)\end{array}$ & $\begin{array}{l}32.22 \\
(7.25-48.76)\end{array}$ & $\begin{array}{l}58.33 \\
(31.15-87.55)\end{array}$ & Clay loam \\
\hline & S8 Gangasagar & $\begin{array}{r}22^{\circ} 38^{\prime} \\
24^{\prime \prime}\end{array}$ & $88^{\circ} 04^{\prime} 46^{\prime \prime}$ & $\begin{array}{l}7.44 \\
(7.13-7.91)\end{array}$ & $\begin{array}{l}0.43 \\
(0.15-0.82)\end{array}$ & $\begin{array}{l}9.98 \\
(6.37-15.54)\end{array}$ & $\begin{array}{l}34.61 \\
(17.29-65.42)\end{array}$ & $\begin{array}{l}28.43 \\
(17.00-40.38)\end{array}$ & $\begin{array}{l}36.96 \\
(16.98-51.6)\end{array}$ & $\begin{array}{l}\text { Clay } \\
\text { loam-sa }\end{array}$ \\
\hline
\end{tabular}

*Classification of sediment grain size (Folk and Ward 1957)

Minimum and maximum value of each parameter is given in parenthesis
$9.98 \%$ at $\mathrm{S} 8$. This is linked to multiple causes like the greater fluvial content of carbonate, in the form of carbonate deposits and flood-related deposit common in tropical settings (Carthew et al. 2003), as well as to greater transport and mixing, especially during the monsoon season, of terrigenous fraction from continental sediments. We also estimated the variation of carbonates at each site over the season, and we observed significant increasing levels from monsoon to pre-monsoon season up to $4.7 \%$ at $\mathrm{S} 7$. The grain size parameters show how the surface sediments of HRE can be classified into two primary textural groups: clay loamy and clay loamy sandy according to the classification of Folk and Ward (1957). Clay is very abundant, with a mean range of $37.0-59.6 \%$ and a maximum in the estuarine site $\mathrm{S} 7,87.55 \%$, with a clear decreasing trend from freshwater to estuary zone due to progressive sedimentation of finest particles. A case apart is represented by $\mathrm{S} 8$ where clay reaches its minimum value, $37 \%$, located at the confluence of $\mathrm{HR}$ and Bay of Bengal, endorsing high-energy zone. Silt contents are rather homogenous with a narrow range of mean variation, 28.43$35.19 \%$, whereas sand shows a higher variability with a mean range of $14.94-15.84 \%$ in the fluvial, $7.45-8.73 \%$ in the brackish and $10.45-34.6 \%$ in the estuary. The dominance of finer sediment, clay and silt, indicates a weak hydrodynamic condition of the estuary and is also an indication of freshwater input with finer particles that settle to the bottom when current and winds reduce. The mean diameters of the surface sediments vary generally from 3.4 to $4.86 \varphi$ and reach their peaks at the mid to lower stretch of the estuary. The coarsest sediments $(<3.5 \varphi)$ occur at $\mathrm{S} 8$ at the mouth of the estuary. The sorting coefficients of the surface sediments varied from 0.575 to $1.03 \varphi$, indicating moderately well sorting in the study region which might be attributed to the relatively better distribution of the finer sediments. Size distributions in the study area were fine skewed, with values of skewness varying from $0.194 \varphi$ at $\mathrm{S}_{3}$ to $0.538 \varphi$ at $\mathrm{S}_{6}$. The main factors affecting the spatial distribution of grain size parameters are sediment sources and characteristics, hydrodynamic conditions and topography features (Liang et al. 2020). Kurtosis analyses show that all samples, except S7, are leptokurtic in nature.

\section{Distribution of trace elements in the sediments and assessment of contamination}

Table 2 reports the range of variation of the trace elements over 2014-2017 for the three HRE salinity areas and along each season. Data were compared with the upper chemical composition of the Earth's continental crust level, ECCL (Taylor and McLennan 1985), used as background, since there are no data on background concentrations for the studied sediments of the region. TEs along the studied period and according to the mean concentration are scaled with the following order: $\mathrm{Fe}>\mathrm{Al}>\mathrm{Mn}>\mathrm{Ni}>\mathrm{Cr}>\mathrm{Zn}>\mathrm{Pb}>-$ $\mathrm{Cu}>\mathrm{Co}>\mathrm{As}>\mathrm{U}>\mathrm{Cd}>\mathrm{Hg}$. Most of them were below the mean level of the upper continental crust except $\mathrm{As}, \mathrm{Cd}, \mathrm{Ni}, \mathrm{Pb}$ and $\mathrm{U}$ which were about four, six, nine, two and twofold the crust means. 


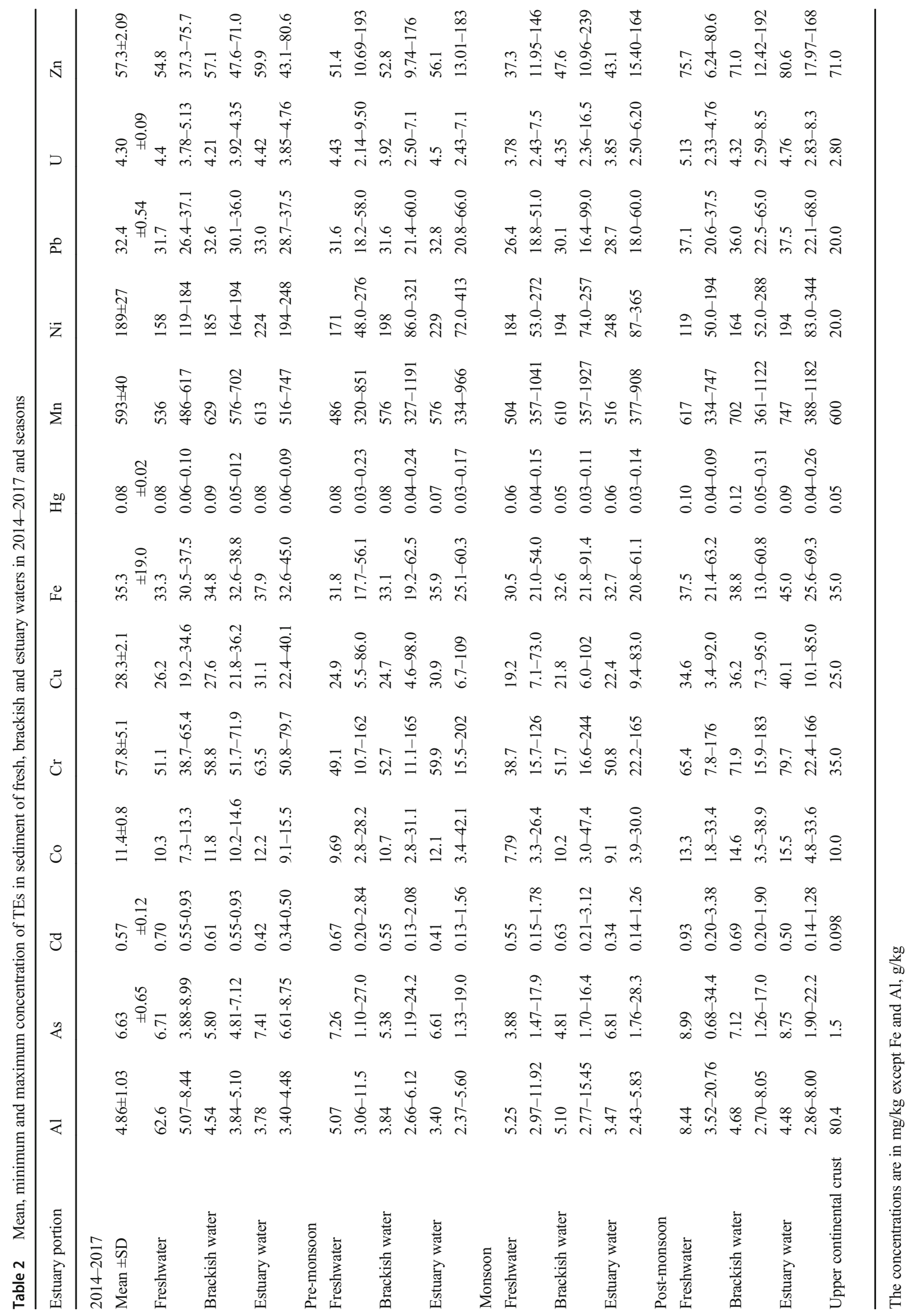


The mean spatial distribution revealed that while Al significantly decreased from the fluvial area toward the mouth of the estuary, 62.6 vs. $37.8 \mathrm{~g} / \mathrm{kg}$, the levels of Fe and Mn tended to increase by $\sim 10-20 \%$. In parallel to this trend, the concentrations of all the other elements, except $\mathrm{Cd}$ which decreased by $40 \%$, increased, as in the case of $\mathrm{Ni}$, up to $29.5 \%$ from the freshwater area to the estuary location. TEs, in fact, tend to bound to amorphous and well-crystallized iron and manganese oxyhydroxides (Yin et al. 2016) and under these forms are transported down the studied estuary. Only the mean levels of $\mathrm{Hg}$ and $\mathrm{U}$ remained nearly unvaried. This trend remains approximately the same over the three different seasons, with a peak of As accumulation during the monsoon in estuary water, 3.88 vs. 6.81 , corresponding to an increase of $75.52 \%$ and of $\mathrm{Ni}$ in the post-monsoon season, 119 vs. 194 , i.e. $\sim 63 \%$. By contrast, $\mathrm{Ni}$ in the post-monsoon season seems to be permanently washed off up to $\sim 15-30 \%$ in the fluvial and brackish area. The lowest mean concentrations of $\mathrm{Co}, \mathrm{Ni}$, $\mathrm{Cu}, \mathrm{Zn}$ and $\mathrm{As}$ were encountered at the sampling site Babughat (S3) during post-monsoon season (November 2016), while the maximum concentration of $\mathrm{Mn}, \mathrm{Fe}, \mathrm{Co}$ and $\mathrm{Zn}$ was recorded at Diamond Harbour (S6) during monsoon season (August 2015).

Table 3 displays the comparison of the mean TEs concentrations over 2014-2017 in superficial sediments with those from the main water courses and the major eastern, western and southern estuary of India and other world spots as South Yellow Sea and Mediterranean coastal areas. On the overall, our results do not result so alarming being the TEs levels of the same order of magnitude or even lower than those of the other considered locations. However, this is not the case of As which is up to tenfold higher than the Ganges (Banerjee et al. 2012) and Krishna estuary (Ramesh et al. 1999) and Tapti and Cochin site (Sharma and Subramanian 2010; Balachandran et al. 2006). The reason for the presence of arsenic is all probably geological as reported by Chakraborty et al. (2018). Also, Ni is rather worrying since its mean level, $190 \mathrm{mg} / \mathrm{kg}$, is fourfold of those from other sites of India and thirteenfold higher of those of the Ganges estuary (Banerjee et al. 2012). All investigated TEs fall within the range of the Mediterranean coastal area (UNEP 1996).

\section{Correlation analysis}

Table 4 reports the output of the Pearson correlation matrix (CM) applied to the data $\mathrm{Al}, \mathrm{As}, \mathrm{Cd}, \mathrm{Cr}, \mathrm{Cu}, \mathrm{Fe}, \mathrm{Hg}, \mathrm{Mn}, \mathrm{Ni}$, $\mathrm{Pb}, \mathrm{U}, \mathrm{Zn}, \mathrm{pH}, \mathrm{C}_{\mathrm{org}} \mathrm{CaCO}_{3}$, sand, silt and clay for freshwater zone. The major outputs of the Pearson's data reveal the absence of any correlation of TEs with clay and silt along the entire stretch of the river examined. Most of TEs, except for $\mathrm{Hg}$, appear significantly correlated, $p<0.05, r$ ranges 0.70 0.99 , highlighting a common source. They are also correlated with $\mathrm{Mn}, r$ ranges $0.70-0.92$, meaning an evident association with this element. This, together with the already observed spatial distribution of Fe and Mn along the estuary, supports the hypothesis that TEs are bound to amorphous and/or crystallized iron and manganese oxyhydroxides. However, Ni differs from this behaviour, for which we observe an important negative correlation with $\mathrm{Co}, \mathrm{Cr}, \mathrm{Cu}$ and $\mathrm{Zn}, \mathrm{r} \sim-075$, indicating a different provenience of the element. Another interesting issue regards the couple $\mathrm{Pb}-\mathrm{U}$ which were highly significantly correlated, $r$ of 0.89 . This finding could be likely linked to the massive presence of the fertilizer industry in the first stretch of the estuary and the use of phosphorites (phosphoric mineral), which, depending on their origin, may have high concentrations of radioactive elements of the natural series uranium, ${ }^{238} \mathrm{U}$, besides thorium, ${ }^{232} \mathrm{Th}$; potassium, ${ }^{40} \mathrm{~K}$; and ${ }^{210} \mathrm{~Pb}$. In phosphoric acid production, the radioactive equilibrium in the phosphate rock is disrupted, with ${ }^{238} \mathrm{U}$ and ${ }^{232} \mathrm{Th}$ and ${ }^{210} \mathrm{~Pb}$ appearing primarily in the phosphoric acid, while the ${ }^{226} \mathrm{Ra}$ and ${ }^{210}$ Po becomes associated with the gypsum waste product (Paul and Pillai 1990). The concentrations of uranium in phosphorite rocks are generally between 30 and $260 \mathrm{mg} / \mathrm{kg}$ and are higher than the average uranium ECCL content of $2.80 \mathrm{mg} / \mathrm{kg}$ (Taylor and McLennan 1985); see Table 1.

Table 5 displays the Pearson's CM for brackish water. In this case, there are a larger number of elements, Al, As, Cd, $\mathrm{Co}, \mathrm{Cr} \mathrm{Cu}, \mathrm{Fe}, \mathrm{Mn}$ and $\mathrm{Pb}$ which appear correlated each to other, with $r$ of $0.72-0.99$. Mn that in freshwater appears correlated only with $\mathrm{Co}, \mathrm{Cr}, \mathrm{Cu}, \mathrm{Fe}$ and $\mathrm{Zn}, r$ of $0.82-0.92$, in brackish water correlates with all set of TEs, $r$ range of 0.73-0.97, and this seems to match with the already higher levels of this element in this water. It is also interesting to note, besides the negative and significant correlation of $\mathrm{Ni}$, that both $\mathrm{Pb}$ and $\mathrm{U}$ correlate with all the studied set of TEs, $r$ of 0.70 0.96. In the case of estuary water, data not shown, the correlation features return almost identical to those of the freshwater.

\section{Factor analysis}

The loading factors, total and cumulative variance generated by the principal component analysis of TEs, $\mathrm{C}_{\mathrm{org}}, \mathrm{CaCO}_{3}$, sand, silt and clay are shown in Table 6 . For freshwater, two principal components account for $59.4 \%$ of total cumulative variance. PC1 explains $48.4 \%$ of total variance and is significantly and negatively correlated with $\mathrm{As}, \mathrm{Cd}, \mathrm{Cr}, \mathrm{Cu}, \mathrm{Fe}$ and $\mathrm{Mn}$ and positively correlated with $\mathrm{Ni}$ with a moderate positive load. PC2 groups have only two significant loads: one is clay, high positive load of 0.94 , and the other is silt, moderate negative significant load of -0.83 . In the case of brackish water, PC1 and PC2 explain $59.1 \%$ and $9.2 \%$ of total cumulative variance with all the elements grouping under component 1 and with positive significant loads. Only Ni displayed a significant negative load of -0.78 . The estuary water shows 
Table 3 Comparison of TEs concentrations in sediments with other fluvial and coastal regions of India and other parts of the world

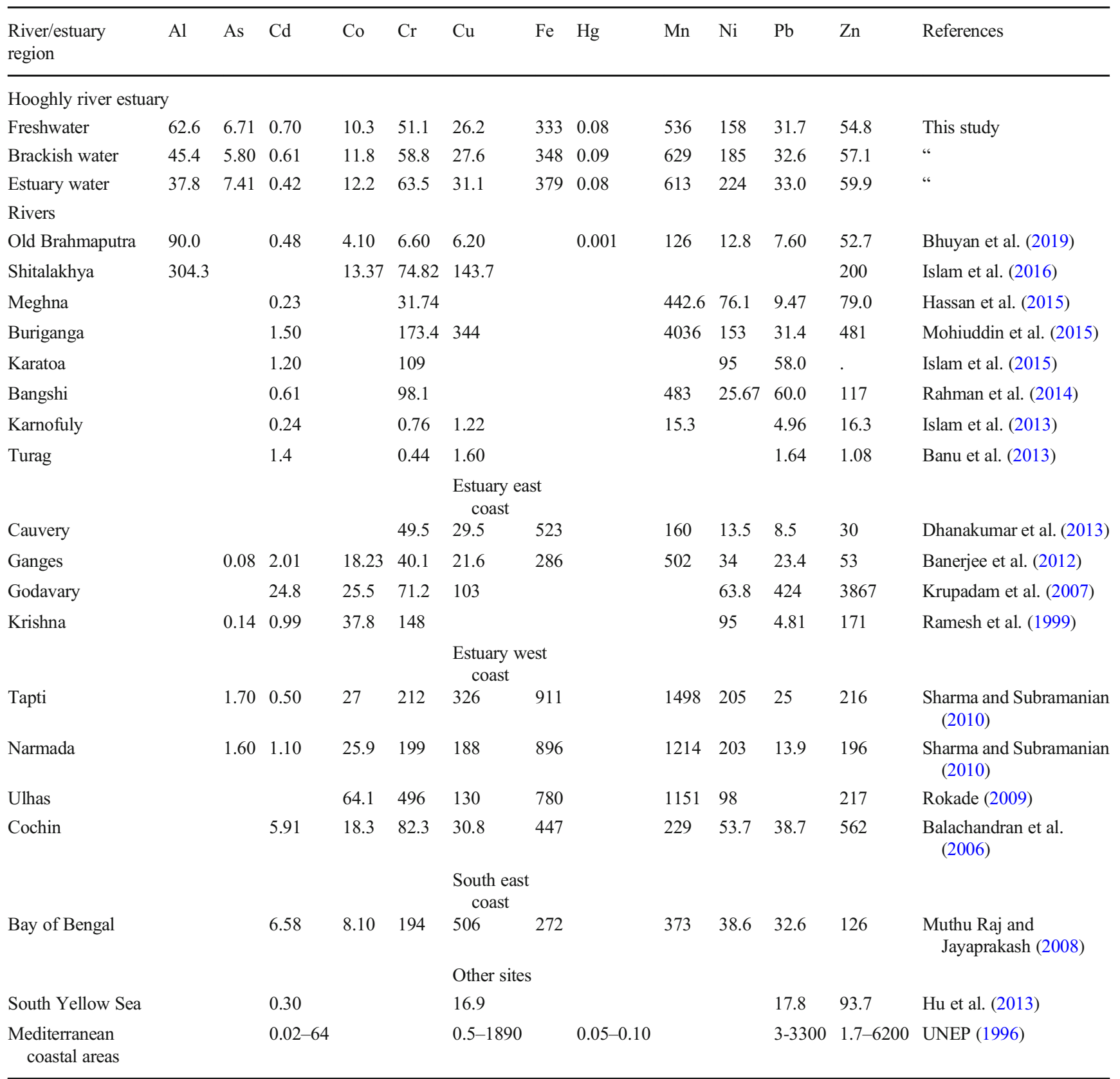

The concentrations are in $\mathrm{mg} / \mathrm{kg}$ except $\mathrm{Fe}$ and $\mathrm{Al}, \mathrm{g} / \mathrm{kg}$

components 1 and 2 explaining 52.8 and $11.7 \%$ of the total variance and with elements grouping all together under PC1 with positive loads except for $\mathrm{Ni}$ and high negative load of 0.92 .

These results confirm those from Pearson's CM showing an evident association of most TEs with major elements Fe and Mn, likely in the form of amorphous or crystalline iron and manganese oxides. Results also highlight the different sources of $\mathrm{Ni}$ and the scant role of the fine clay and silt fractions from terrestrial debris.

\section{Hierarchical cluster analysis}

The hierarchical cluster analysis (HCA), Fig. 2, was performed by the criteria of Ward (Lebart et al. 1984). The diagrams allow us to clearly recognize for all the three water systems two main clusters, $\mathrm{A}$ and $\mathrm{B}$, that are very distinct at high hierarchical level. This means that the variables split into two main groups which clearly characterize the estuary: cluster A including clay, $\mathrm{CaCO}_{3}, \mathrm{pH}$, sand, clay and $\mathrm{Ni}$ and cluster $\mathrm{B}$ including all elements, with very short distance between $\mathrm{Al}, \mathrm{Fe}$ and $\mathrm{Mn}$ from 
Table 4 Correlation coefficients among TEs, $\mathrm{pH}, \mathrm{C}_{\text {org }}, \mathrm{CaCO}_{3}$, sand, silt and clay for freshwater sites

\begin{tabular}{|c|c|c|c|c|c|c|c|c|c|c|c|c|c|c|c|c|c|c|c|}
\hline & $\mathrm{Al}$ & As & $\mathrm{Cd}$ & $\mathrm{Co}$ & $\mathrm{Cr}$ & $\mathrm{Cu}$ & $\mathrm{Fe}$ & $\mathrm{Hg}$ & $\mathrm{Mn}$ & $\mathrm{Ni}$ & $\mathrm{Pb}$ & $\mathrm{U}$ & $\mathrm{Zn}$ & $\mathrm{pH}$ & $\mathrm{C}_{\text {org }}$ & $\mathrm{CaCO}_{3}$ & Sand & Silt & Clay \\
\hline $\mathrm{Al}$ & 1.00 & & & & & & & & & & & & & & & & & & \\
\hline As & 0.27 & 1.00 & & & & & & & & & & & & & & & & & \\
\hline $\mathrm{Cd}$ & $0 . .35$ & 0.64 & 1.00 & & & & & & & & & & & & & & & & \\
\hline Co & 0.45 & 0.91 & 0.68 & 1.00 & & & & & & & & & & & & & & & \\
\hline $\mathrm{Cr}$ & 0.44 & 0.92 & 0.67 & 0.99 & 1.00 & & & & & & & & & & & & & & \\
\hline $\mathrm{Cu}$ & 0.42 & 0.91 & 0.65 & 0.98 & .98 & 1.00 & & & & & & & & & & & & & \\
\hline $\mathrm{Fe}$ & 0.55 & 0.69 & 0.54 & 0.83 & 0.81 & 0.81 & 1.00 & & & & & & & & & & & & \\
\hline $\mathrm{Hg}$ & 0.15 & 0.39 & 0.30 & 0.39 & 0.36 & 0.41 & 0.40 & 1.00 & & & & & & & & & & & \\
\hline $\mathrm{Mn}$ & 0.60 & 0.70 & 0.60 & 0.85 & 0.84 & 0.83 & 0.92 & 0.40 & 1.00 & & & & & & & & & & \\
\hline $\mathrm{Ni}$ & -0.58 & -0.67 & -0.54 & -0.74 & -0.75 & -0.73 & -0.59 & -0.28 & -0.68 & 1.00 & & & & & & & & & \\
\hline $\mathrm{Pb}$ & 0.34 & 0.48 & 0.48 & 0.54 & 0.54 & 0.55 & 0.46 & 0.30 & 0.43 & -0.42 & 1.00 & & & & & & & & \\
\hline $\mathrm{U}$ & 0.41 & 0.56 & 0.47 & 0.60 & 0.61 & 0.059 & 0.49 & 0.20 & 0.48 & -0.50 & 0.89 & 1.00 & & & & & & & \\
\hline $\mathrm{Zn}$ & 0.45 & 0.92 & 0.70 & 0.99 & 0.99 & 0.99 & 0.81 & 0.38 & 0.84 & -0.76 & 0.54 & 0.60 & 1.00 & & & & & & \\
\hline $\mathrm{pH}$ & -0.12 & -0.29 & -0.21 & -0.34 & -0.34 & -0.31 & -0.26 & 0.14 & -0.29 & 0.08 & -0.01 & -0.13 & -0.33 & 1.00 & & & & & \\
\hline $\mathrm{C}_{\text {org }}$ & 0.09 & 0.26 & 0.36 & 0.23 & 0.20 & 0.22 & 0.16 & 0.14 & 0.21 & $0-.21$ & 0.08 & 0.10 & 0.24 & -0.11 & 1.00 & & & & \\
\hline $\mathrm{CaCO}_{3}$ & 0.04 & 0.16 & 0.06 & 0.16 & 0.14 & 0.17 & 0.26 & 0.09 & 0.12 & 0.03 & 0.08 & 0.04 & 0.16 & -0.07 & 0.03 & 1.00 & & & \\
\hline Sand & -0.022 & -0.48 & -0.49 & -0.52 & -0.50 & -0.51 & -0.41 & -0.39 & -0.45 & 0.28 & -0.34 & -0.27 & -0.50 & 0.26 & -0.26 & -0.21 & 1.00 & & \\
\hline Silt & 0.28 & 0.23 & 0.23 & 0.28 & 0.26 & 0.24 & 0.38 & 0.25 & 0.41 & -0.24 & 0.01 & 0.09 & 0.26 & -0.28 & 0.20 & -0.05 & -0.23 & 1.00 & \\
\hline Clay & -0.12 & 0.09 & 0.11 & 0.08 & 0.08 & 0.11 & -0.09 & 0.02 & -0.09 & 0.04 & 0.21 & 0.09 & 0.09 & 0.09 & -0.02 & 0.18 & -0.44 & -0.78 & 1.00 \\
\hline
\end{tabular}

In bold the values statistically significant $(p<0.05)$

one side and narrow distance between $\mathrm{Pb}$ and $\mathrm{U}$, once again confirming the role of the major elements, $\mathrm{Al}, \mathrm{Fe}$ and $\mathrm{Mn}$ in enriching and transporting elements along the estuary.

\section{Index of geoaccumulation (Igeo)}

The degree of contamination was assessed by the geoaccumulation index (Igeo); enrichment factor, EF; contamination factor $(\mathrm{CF})$; contamination degree, $\mathrm{Cd}$; modified contamination degree, mCD; pollution load index, PLI; and potential contamination index, Cp (Muller 1969; Bryan and
Langston 1992; Ravichandran et al. 1995; Buccolieri et al. 2006; Vaezi et al. 2016; Barbieri 2016; Arienzo et al. 2020a, 2020b) (Tables 7, 8, 9).

Igeo was calculated from the ECCL (Taylor and McLennan 1985) used as background, and results interpreted according to the seven grades proposed by Müller (1981). Table 7 shows how a heavily to extremely contaminated class was individuated for $\mathrm{Ni}, 3<$ Igeo $<4$, at all sites, with an extremely contaminated situation at the estuary, $\sim 4$. The second worrying situation was found for $\mathrm{Cd}$ in correspondence of the freshwater location, with mean Igeo values of 3.38 , falling in

Table 5 Correlation coefficients among TEs, $\mathrm{pH}, \mathrm{C}_{\text {org }}, \mathrm{CaCO}_{3}$, sand, silt and clay for brackish water sites

\begin{tabular}{|c|c|c|c|c|c|c|c|c|c|c|c|c|c|c|c|c|c|c|c|}
\hline & $\mathrm{Al}$ & As & $\mathrm{Cd}$ & $\mathrm{Co}$ & $\mathrm{Cr}$ & $\mathrm{Cu}$ & $\mathrm{Fe}$ & $\mathrm{Hg}$ & $\mathrm{Mn}$ & $\mathrm{Ni}$ & $\mathrm{Pb}$ & $\mathrm{U}$ & $\mathrm{Zn}$ & $\mathrm{pH}$ & $\mathrm{C}_{\text {org }}$ & $\mathrm{CaCO}_{3}$ & Sand & Silt & Clay \\
\hline $\mathrm{Al}$ & 1.00 & & & & & & & & & & & & & & & & & & \\
\hline As & 0.43 & 1.00 & & & & & & & & & & & & & & & & & \\
\hline $\mathrm{Cd}$ & 0.72 & 0.74 & 1.00 & & & & & & & & & & & & & & & & \\
\hline Co & 0.65 & 0.89 & 0.90 & 1.00 & & & & & & & & & & & & & & & \\
\hline $\mathrm{Cr}$ & 0.67 & 0.90 & 0.90 & 1.00 & 1.00 & & & & & & & & & & & & & & \\
\hline $\mathrm{Cu}$ & 0.59 & 0.92 & 0.83 & 0.98 & 0.98 & 1.00 & & & & & & & & & & & & & \\
\hline $\mathrm{Fe}$ & 0.73 & 0.73 & 0.79 & 0.85 & 0.85 & 0.84 & 1.00 & & & & & & & & & & & & \\
\hline $\mathrm{Hg}$ & 0.11 & 0.32 & 0.21 & 0.36 & 0.32 & 0.39 & 0.33 & 1.00 & & & & & & & & & & & \\
\hline $\mathrm{Mn}$ & 0.79 & 0.73 & 0.83 & 0.86 & 0.87 & 0.83 & 0.97 & 0.32 & 1.00 & & & & & & & & & & \\
\hline $\mathrm{Ni}$ & -0.54 & -0.74 & -0.69 & -0.76 & -0.74 & -0.75 & -0.72 & -0.41 & -0.73 & 1.00 & & & & & & & & & \\
\hline $\mathrm{Pb}$ & 0.70 & 0.81 & 0.87 & 0.95 & 0.95 & 0.92 & 0.80 & 0.21 & 0.81 & -0.66 & 1.00 & & & & & & & & \\
\hline $\mathrm{U}$ & 0.80 & 0.71 & 0.88 & 0.88 & 0.89 & 0.82 & 0.77 & 0.12 & 0.81 & -0.60 & 0.96 & 1.00 & & & & & & & \\
\hline $\mathrm{Zn}$ & 0.64 & 0.91 & 0.88 & 0.99 & 0.99 & 0.98 & 0.85 & 0.36 & 0.87 & -0.78 & 0.94 & 0.87 & 1.00 & & & & & & \\
\hline $\mathrm{pH}$ & -0.16 & -0.19 & -0.12 & -0.21 & -0.21 & -0.21 & -0.15 & -0.24 & -0.19 & 0.15 & -0.18 & -0.19 & -0.22 & 1.00 & & & & & \\
\hline $\mathrm{C}_{\text {org }}$ & 0.11 & 0.45 & 0.19 & 0.33 & 0.33 & 0.40 & 0.40 & 0.40 & 0.34 & -0.30 & 0.28 & 0.17 & 0.35 & -0.37 & 1.00 & & & & \\
\hline $\mathrm{CaCO}_{3}$ & 0.01 & 0.19 & 0.09 & 0.19 & 0.20 & 0.22 & 0.22 & 0.25 & 0.19 & -0.09 & 0.11 & 0.06 & 0.19 & 0.02 & 0.14 & 1.00 & & & \\
\hline Sand & -0.18 & -0.38 & -0.30 & -0.41 & -0.40 & -0.44 & -0.33 & -0.03 & -0.35 & 0.26 & -0.35 & -0.28 & -0.39 & -0.13 & -0.06 & -0.14 & 1.00 & & \\
\hline Silt & 0.54 & 0.46 & 0.52 & 0.60 & 0.59 & 0.56 & 0.55 & 0.21 & 0.59 & -0.40 & 0.61 & 0.56 & 0.58 & -0.07 & 0.05 & 0.19 & -0.51 & 1.00 & \\
\hline Clay & -0.54 & -0.40 & -0.49 & -0.55 & -0.53 & -0.48 & -0.51 & -0.22 & -0.56 & 0.37 & -0.57 & -0.54 & -0.52 & 0.13 & -0.03 & -0.17 & 0.24 & -0.96 & 1.00 \\
\hline
\end{tabular}

In bold the values statistically significant $(p<0.05)$ 
Table 6 Loading factors, total and cumulative variance of TEs, $\mathrm{pH}$, $\mathrm{CaCO}_{3}$, sand, silt and clay for fresh, brackish and estuary water

\begin{tabular}{|c|c|c|c|c|c|c|}
\hline & \multicolumn{2}{|c|}{ Freshwater } & \multicolumn{2}{|c|}{ Brackish water } & \multicolumn{2}{|c|}{ Estuary water } \\
\hline & PC1 & PC2 & $\mathrm{PC} 1$ & $\mathrm{PC} 2$ & PC1 & $\mathrm{PC} 2$ \\
\hline $\mathrm{Al}$ & -0.55 & -0.23 & 0.74 & 0.27 & 0.71 & 0.32 \\
\hline As & -0.89 & 0.08 & 0.87 & -0.21 & 0.92 & -0.09 \\
\hline $\mathrm{Cd}$ & -0.74 & 0.07 & 0.90 & 0.10 & 0.83 & -0.22 \\
\hline Co & -0.97 & 0.02 & 0.98 & -0.04 & 0.96 & -0.15 \\
\hline $\mathrm{Cr}$ & -0.96 & 0.03 & 0.98 & -0.03 & 0.97 & -0.15 \\
\hline $\mathrm{Cu}$ & -0.96 & 0.07 & 0.96 & -0.12 & 0.96 & -0.15 \\
\hline $\mathrm{Fe}$ & -0.86 & -0.16 & 0.90 & -0.05 & 0.90 & 0.16 \\
\hline $\mathrm{Hg}$ & -0.45 & 0.02 & 0.36 & -0.55 & 0.42 & 0.17 \\
\hline $\mathrm{Mn}$ & -0.89 & -0.20 & 0.92 & 0.01 & 0.92 & 0.12 \\
\hline $\mathrm{Ni}$ & 0.77 & 0.10 & -0.78 & 0.17 & -0.90 & 0.07 \\
\hline $\mathrm{Pb}$ & -0.63 & 0.34 & 0.94 & 0.09 & 0.93 & -0.05 \\
\hline $\mathrm{U}$ & -0.68 & 0.21 & 0.90 & 0.18 & 0.74 & 0.06 \\
\hline $\mathrm{Zn}$ & -0.97 & 0.04 & 0.98 & -0.08 & 0.98 & -0.14 \\
\hline $\mathrm{pH}$ & 0.32 & 0.24 & -0.22 & 0.49 & 0.15 & 0.14 \\
\hline Corg & -0.28 & -0.09 & 0.36 & -0.71 & 0.25 & 0.11 \\
\hline $\mathrm{CaCO}_{3}$ & -0.17 & 0.24 & 0.20 & -0.17 & 0.02 & -0.52 \\
\hline Sand & 0.57 & -0.28 & -0.42 & -0.29 & 0.15 & 0.92 \\
\hline Silt & -0.34 & -0.83 & 0.68 & 0.44 & 0.20 & -0.14 \\
\hline Clay & -0.05 & 0.94 & -0.63 & -0.40 & -0.25 & -0.85 \\
\hline Initial eigenvalue & 9.20 & 2.07 & 11.23 & 1.74 & 10.04 & 12.24 \\
\hline$\%$ total variance & 48.4 & 10.9 & 59.1 & 9.2 & 52.8 & 11.7 \\
\hline$\%$ cumulative variance & 48.4 & 59.4 & 59.1 & 68.3 & 52.8 & 64.5 \\
\hline
\end{tabular}

In bold the significant loads, $p<0.05$

heavily contaminated class and with no significant differences among seasons. Whatever was the season, brackish and estuary water showed lower Igeo mean values, 2.68 and 2.20, respectively, falling in the class of moderately contaminated-heavily contaminated class, $2<$ Igeo $<3$. A similar trend was observed for As, but with mean Igeo values falling in the class of moderately contaminated-heavily contaminated class in most of the estuary.

\section{Enrichment factor (EF)}

Table 7 also shows the EF values calculated using Fe as normalizer (Zhang and Liu 2002). Where the index is $>1.5$, the source of the element is due to anthropic pollution and not to crustal materials or natural weathering processes. This is the case in decreasing order of $\mathrm{Ni}, \mathrm{Cd}, \mathrm{As}, \mathrm{Pb}, \mathrm{U}$ and $\mathrm{Hg}$. $\mathrm{EF}$ values of Ni were very high, in the range of 9.89-12.37, with an increasing trend oriented to the estuary water where the recorded peak was up to $\sim 10$ fold 1.5 , while in the case of $\mathrm{As}, \mathrm{Cd}$ and $\mathrm{Pb}$ pollution which was rather similar at all sites and over the three seasons, Ni reached the highest peaks during the monsoon and at all sites. Multiple sources of $\mathrm{Ni}$ pollution could be identified like metallurgical activity, petroleum refineries, intensive activities of the bay shipyards of the HRE where vessels are maintained and repaired and the intense use of antifouling paints (Nemr et al. 2006; Costa et al. 2016). This finding seems to match with those from a study on the HRE water (Mukherjee et al. 2015): authors revealed that $\mathrm{Ni}$ and $\mathrm{Cd}$ significantly accumulated in the most consumed fishery resources of Hooghly area, Mystus cavasius and Glossogobius giuris posing a great risk for public health since elements go beyond the permissible level.

\section{Contamination factor (Cf), modified contamination factor (mCD)}

The contamination factor $\mathrm{Cf}$ of each element, Table 8 , was used to evaluate the contamination of the single trace element (Jiang et al. 2013; Kerolli-Mustafa et al. 2015). The contamination levels were classified based on their intensities on a scale, ranging from 1 to 6 (Hakanson 1980). Based on their mean Cf values and over 2014-2017, TEs ordered with the following sequence: $\mathrm{Ni}>\mathrm{Cd}>\mathrm{As}>\mathrm{Hg}>\mathrm{Cr}>\mathrm{Pb}>\mathrm{U}>\mathrm{Co}>\mathrm{Cu}>\mathrm{Fe}>\mathrm{Mn}>\mathrm{Zn}>\mathrm{Al}$. $\mathrm{Cf}$ of $\mathrm{Ni}$ was $>6$ and displayed higher peaks in the estuary water, up to 12.4; that of $\mathrm{Cd}$ was close to 6 especially during post-monsoon and decreases toward the outer estuary. Thus, both $\mathrm{Ni}$ and $\mathrm{Cd}$ represented a very high contamination situation, as was in the class of considerable contamination, whereas $\mathrm{Co}, \mathrm{Cr}, \mathrm{Cu}, \mathrm{Fe}$, $\mathrm{Mn}, \mathrm{Pb}$ and $\mathrm{U}$ fall in the class of moderate contamination with $\mathrm{Cf}$ ranging between 1 and 3 . From this index, two further indexes were calculated, the contamination degree, $\mathrm{CD}$, which represents the sum of the contamination factors, and the modified contamination degree $(\mathrm{mCD})$ calculated summing the single $\mathrm{Cf}$ values divided by the number of TEs. According to the classification of $\mathrm{mCD}$ proposed by Abrahim and Parker (2008) and to the mean values of $\mathrm{mCD}$ of $\sim 2.50$, the HRE was polluted at a moderate degree, $2<\mathrm{mCD}<4$, with limited spatial and temporal differences.

\section{Pollution load index (PLI)}

The pollution load index PLI according to Tomlinson et al. (1980) was also calculated. Sekabira et al. (2010) reported that PLI > 1 indicated anthropogenic inputs. Data reveal how the index was high at all sites with a mean HRE value of 1.41 and tendentially lower values, $\sim 1.20$, during the monsoon.

\section{Potential contamination index (Cp)}

Finally, the potential contamination index, $\mathrm{Cp}$, was calculated by the method of Hakanson (1980). Davaulter and Rognerud (2001) proposed low contamination if $\mathrm{Cp}<1$, moderate contamination $1<\mathrm{Cp}<3$ and severe or very severe contamination $\mathrm{Cp}>3$. Table 9 shows how most of 
Fig. 2 Output of hierarchical cluster analysis (HCA). Letters indicate clusters
Freshwater

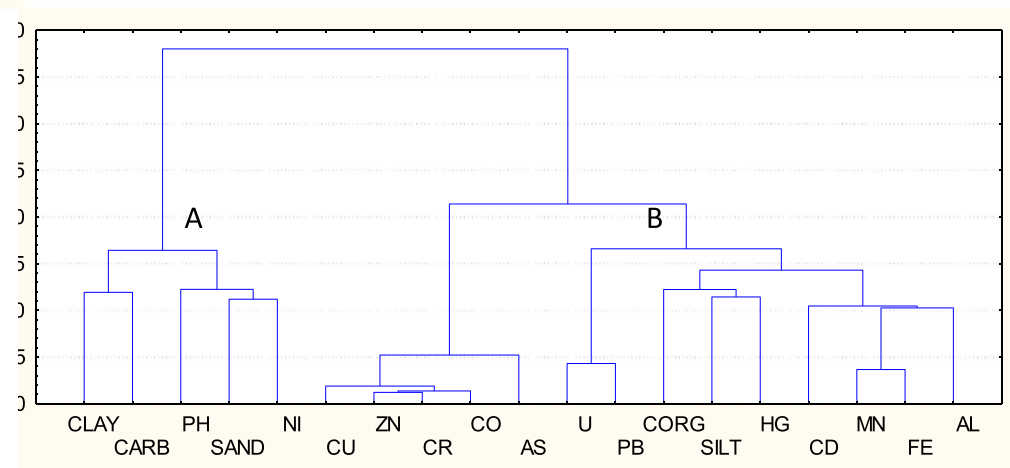

Brackish water

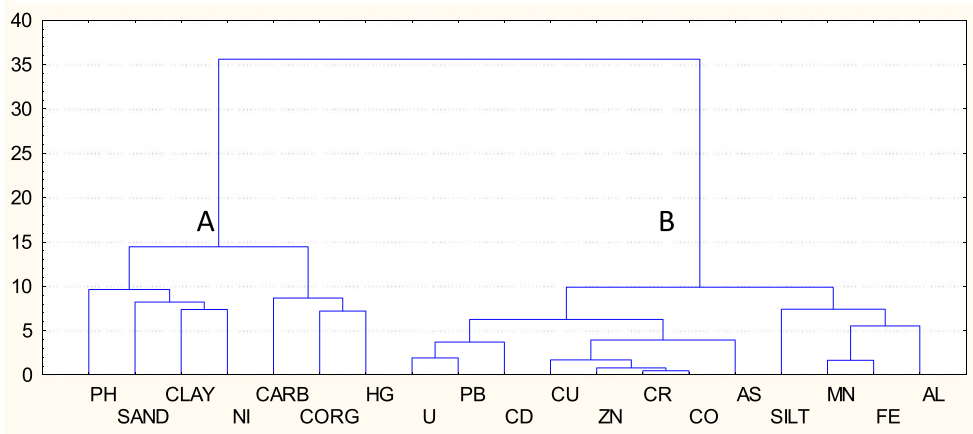

Estuary water

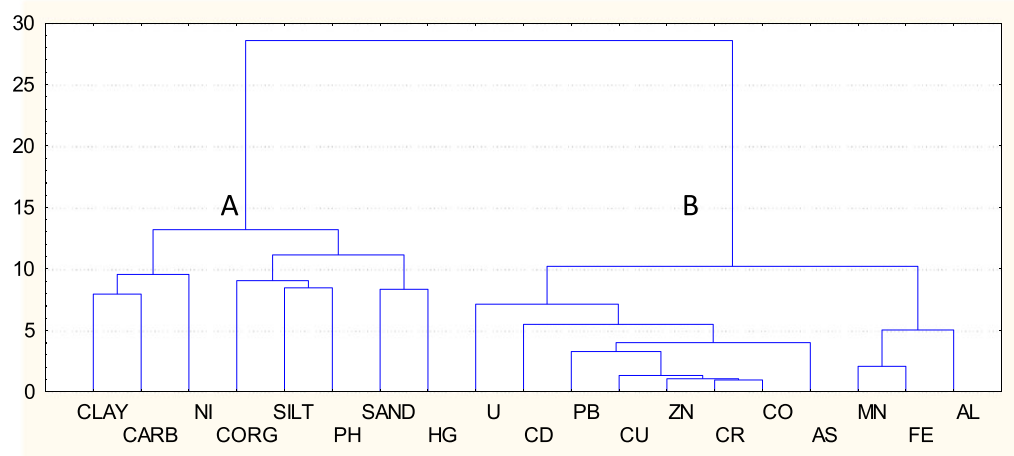

TEs presented $\mathrm{Cp}$ values greater than 6 , and hence, sediments were very severely contaminated with values for $\mathrm{Cd}$, $\mathrm{Ni}$ and As of 9-, 6- and 6-fold the limit of the heavier polluted class, with worst situation for As and $\mathrm{Cd}$ at fresh and brackish water and during post-monsoon evidencing a rapid recharge of the pollution after monsoon and for $\mathrm{Ni}$ at estuary water during monsoon.

\section{Potential ecological risk index (Er)}

In order to define the ecological risk in aquatic system, we calculated the potential ecological risk index, Er, as proposed by Hakanson (1980). The index serves to establish the degree of trace element pollution in sediments, according to the individual toxicity of TEs and the response of the environment. 
Table 7 Geoaccumulation index (Igeo) and enrichment factor (EF)

\begin{tabular}{|c|c|c|c|c|c|c|c|c|c|c|c|c|}
\hline & $\mathrm{Al}$ & As & $\mathrm{Cd}$ & $\mathrm{Co}$ & $\mathrm{Cr}$ & $\mathrm{Cu}$ & $\mathrm{Hg}$ & Mn & $\mathrm{Ni}$ & $\mathrm{Pb}$ & $\mathrm{U}$ & $\mathrm{Zn}$ \\
\hline \multicolumn{13}{|c|}{ Freshwater } \\
\hline Igeo & -2.582 & 2.457 & 3.380 & 0.511 & 0.995 & 0.473 & 1.296 & 0.333 & 3.174 & 1.295 & 1.297 & -0.051 \\
\hline $\mathrm{EF}$ & 0.080 & 4.013 & 7.257 & 0.943 & 1.337 & 0.943 & 1.580 & 0.940 & 9.89 & 1.720 & 1.707 & 0.677 \\
\hline \multicolumn{13}{|c|}{ Brackish water } \\
\hline Igeo & -3.740 & 1.926 & 2.677 & 0.256 & 0.740 & 0.094 & 0.855 & 0.481 & 3.648 & 1.155 & 0.995 & -0.504 \\
\hline $\mathrm{EF}$ & 0.05 & 3.04 & 4.87 & 0.90 & 1.29 & 0.85 & 1.31 & 0.96 & 11.48 & 1.55 & 1.39 & 0.57 \\
\hline \multicolumn{13}{|c|}{ Estuary water } \\
\hline Igeo & -3.954 & 2.194 & 2.201 & 0.406 & 0.963 & 0.317 & 0.785 & 0.505 & 3.872 & 1.189 & 1.145 & -0.311 \\
\hline $\mathrm{EF}$ & 0.04 & 3.88 & 3.51 & 1.00 & 1.49 & 0.99 & 1.24 & 0.95 & 12.37 & 1.71 & 1.52 & 0.68 \\
\hline
\end{tabular}

\section{Comprehensive potential ecological risk index (RI)}

From the Er index, it was calculated the comprehensive potential ecological risk index RI as the sum of all risk factors which was rated according to the method of Devanesan et al. (2017). $R I$ represents the sensitivity of various biological communities to toxic substances and illustrates the potential ecological risk caused by TEs.

The $\mathrm{Er}$ of $\mathrm{Cr}, \mathrm{Cu}, \mathrm{Pb}$ and $\mathrm{Zn}$, Table 10, was all below 40, placing these elements at low ecological risk level, the average Er of As and Ni classified these TEs at most sites and seasons at moderate risk level, whereas the $\mathrm{Er}$ of $\mathrm{Cd}$ falls in the higher-risk class with a peak of 284 at the freshwater site and in the post-monsoon season and a significant decreasing trend toward the outer part of the estuary. The $R I$ values, Table 10, were clearly related to the degree of anthropogenic disturbance. The global risk is severe, $300 \leq \mathrm{RI}<600$, at all sites and seasons and especially after the monsoon, especially at fluvial and brackish locations where it is likely that intense anthropic discharge leads to increasing deposition of chemical elements. This scenario seems to link quite well with the recent study from NACER (2020) on the livelihood and health challenges faced by riverine communities of Ganga. The study found how fisher folk depends on river Ganga's water for drinking and is likely to report higher incidences of diseases such as pneumonia, diarrhoea, cholera, cough/cold, fever, skin disease, typhoid and jaundice.

\section{Conclusions}

The present study quantified and assessed the natural enrichment or anthropogenic sources, contamination levels and toxicity of TEs and $U$ in sediment samples from the terminal stretch of the Hooghly river during the period 2014-2017. This study shows that the major sources of TEs contamination are land-based anthropogenic ones. It shows that the distribution and transportation of these elements in sediments are not uniform and the change in concentration is due to season alternance of dry and wet weather conditions besides man-made flows, water physico-chemical features, sedimentation and hydrodynamic conditions. $\mathrm{Cf}$ index shows how both $\mathrm{Ni}$ and $\mathrm{Cd}$, even though with different spatial and seasonal behaviours, represented a very high contamination situation, whereas the Cp and PLI values revealed that sediments were very severely contaminated by most TEs. Based on the individual ecological risk, $\mathrm{As}, \mathrm{Cd}$ and $\mathrm{Ni}$ are at moderate risk level, whereas global risk was severe closer to man-made inputs, where artisanal gold mining activities, agricultural runoff, lithology and other anthropogenic inputs are probable

Table 8 Contamination factor $(\mathrm{Cf})$, modified contamination degree (mCD) and pollution load index (PLI)

\begin{tabular}{|c|c|c|c|c|c|c|c|c|c|c|c|c|c|c|}
\hline \multicolumn{13}{|l|}{$\mathrm{Cf}$} & \multirow[t]{2}{*}{$\mathrm{mCd}$} & \multirow[t]{2}{*}{ PLI } \\
\hline $\mathrm{Al}$ & As & $\mathrm{Cd}$ & Co & $\mathrm{Cr}$ & $\mathrm{Cu}$ & $\mathrm{Fe}$ & $\mathrm{Hg}$ & $\mathrm{Mn}$ & $\mathrm{Ni}$ & $\mathrm{Pb}$ & $\mathrm{U}$ & $\mathrm{Zn}$ & & \\
\hline \multicolumn{15}{|c|}{ Freshwater } \\
\hline 0.08 & 4.47 & 7.31 & 1.03 & 1.46 & 1.05 & 0.95 & 1.60 & 0.89 & 7.90 & 1.59 & 1.59 & 0.77 & 2.36 & 1.39 \\
\hline \multicolumn{15}{|c|}{ Brackish water } \\
\hline 0.06 & 3.85 & 6.36 & 1.18 & 1.68 & 1.10 & 1.00 & 1.67 & 1.05 & 9.27 & 1.63 & 1.50 & 0.80 & 2.39 & 1.41 \\
\hline \multicolumn{15}{|c|}{ Estuary water } \\
\hline 0.05 & 4.93 & 4.25 & 1.22 & 1.81 & 1.25 & 1.08 & 1.47 & 1.02 & 11.18 & 1.65 & 1.56 & 0.85 & 2.49 & 1.43 \\
\hline
\end{tabular}


Table 9 Potential contamination index $(\mathrm{Cp})$

\begin{tabular}{|c|c|c|c|c|c|c|c|c|c|c|c|c|}
\hline $\mathrm{Al}$ & As & $\mathrm{Cd}$ & $\mathrm{Co}$ & $\mathrm{Cr}$ & $\mathrm{Cu}$ & $\mathrm{Fe}$ & $\mathrm{Hg}$ & $\mathrm{Mn}$ & $\mathrm{Ni}$ & $\mathrm{Pb}$ & $\mathrm{U}$ & $\mathrm{Zn}$ \\
\hline \multicolumn{13}{|c|}{ Freshwater } \\
\hline 0.18 & 17.6 & 27.2 & 2.93 & 4.42 & 3.35 & 1.65 & 3.1 & 1.46 & 12.4 & 2.44 & 2.59 & 1.97 \\
\hline \multicolumn{13}{|c|}{ Brackish water } \\
\hline 0.12 & 12.8 & 24.1 & 3.91 & 5.64 & 3.93 & 2.05 & 4.4 & 2.35 & 14.4 & 3.73 & 3.82 & 2.85 \\
\hline \multicolumn{13}{|c|}{ Estuary water } \\
\hline 0.1 & 15.5 & 13.9 & 3.52 & 5.07 & 3.69 & 1.82 & 3.8 & 1.70 & 18.7 & 3.23 & 2.57 & 2.42 \\
\hline
\end{tabular}

Table 10 Potential ecological risk factors, Er, and comprehensive ecological hazard index, RI

\begin{tabular}{|c|c|c|c|c|c|c|c|c|}
\hline \multicolumn{8}{|l|}{$\mathrm{Er}$} & \multirow[t]{2}{*}{ RI } \\
\hline As & $\mathrm{Cd}$ & $\mathrm{Cr}$ & $\mathrm{Cu}$ & $\mathrm{Hg}$ & $\mathrm{Ni}$ & $\mathrm{Pb}$ & $\mathrm{Zn}$ & \\
\hline \multicolumn{9}{|c|}{ Freshwater } \\
\hline 44.8 & 219 & 2.9 & 5.2 & 59 & 40 & 7.9 & 0.8 & 380 \\
\hline \multicolumn{9}{|c|}{ Brackish water } \\
\hline 38 & 190 & 3.4 & 5.5 & 58 & 46 & 8.1 & 0.8 & 351 \\
\hline \multicolumn{9}{|c|}{ Estuary water } \\
\hline 49 & 127 & 3.6 & 6.2 & 53 & 56 & 8.3 & 0.8 & 304 \\
\hline
\end{tabular}

sources of TEs pollution. Results evidence the need for effective and efficient management policies to control TEs discharge into the estuary and detrimental effects on the nearby mangrove forest of Sundarbans.

Acknowledgements Author Priyanka Mondal is grateful to the Department of Science and Technology (DST) for awarding her a research fellowship under "Innovation in Science Pursuit for Inspired Research (INSPIRE)" programme.

Author contribution Marco Trifuoggi: Conceptualization, methodology, and investigation. Luciano Ferrara: Conceptualization, methodology, and writing - original draft. Maria Toscanesi: Data curation, formal analysis, and validation. Priyanka Mondal: Investigation, formal analysis, and validation. Jonathan Muthuswamy Ponniah: Investigation, formal analysis, and validation. Santosh Kumar Sarkar: Investigation, formal analysis, and validation. Michele Arienzo: Writing original draft, conceptualization, methodology, and review and editing.

Funding Open access funding provided by Università degli Studi di Napoli Federico II within the CRUI-CARE Agreement. The research work was financially supported by the Department of Science and Technology (DST), New Delhi, India [sanction no.: DST/INSPIRE Fellowship/2014/IF140943], in a research project titled "Distribution and possible sources of trace metals in sediments along the Hooghly Estuary and Sundarban Mangrove Wetland, India and their ecotoxicological significance."

Data Availability All data generated or analysed during this study are included in this published article (and its supplementary information files.

\section{Declarations}

Ethics approval Not applicable

Consent to participate Not applicable.

Consent for publication We do give our consent to publish our data.

Competing interests The authors declare no competing interests.

Open Access This article is licensed under a Creative Commons Attribution 4.0 International License, which permits use, sharing, adaptation, distribution and reproduction in any medium or format, as long as you give appropriate credit to the original author(s) and the source, provide a link to the Creative Commons licence, and indicate if changes were made. The images or other third party material in this article are included in the article's Creative Commons licence, unless indicated otherwise in a credit line to the material. If material is not included in the article's Creative Commons licence and your intended use is not permitted by statutory regulation or exceeds the permitted use, you will need to obtain permission directly from the copyright holder. To view a copy of this licence, visit http://creativecommons.org/licenses/by/4.0/.

\section{References}

Abrahim GMS, Parker RJ (2008) Assessment of heavy metal enrichment factors and the degree of contamination in marine sediments from Tamaki Estuary, Auckland. New Zealand. Estuar Coast Shelf Sci $136: 227-238$

Antizar-Ladislao B, Mondal P, Mitra S, Sarkar SK (2015) Assessment of trace metal contamination level and toxicity in sediments from coastal regions of West Bengal, eastern part of India. Mar Pollut Bull 101:886-894

APAT-IRSA CNR, (2003). Metodi Analitici per le Acque Metodo. 4010 Man. 29/03, Rome

Arienzo M, Bolinesi F, Aiello G, Barra D, Donadio C, Stanislao C, Ferrara L, Mangoni O, Toscanesi M, Giarra A, Tirfuoggi M (2020a) The environmental assessment of an estuarine transitional environment, Southern Italy. Journal Marine Science \& Engineering 8:628

Arienzo M, Ferrara L, Toscanesi M, Giarra A, Donadio C, Trifuoggi M (2020b) Sediment contamination by heavy metals and ecological risk assessment: the case of Gulf of Pozzuoli, Naples, Italy. Mar Pollut Bull 155:111149. https://doi.org/10.1016/j.marpolbul.2020.111149

Balachandran KK, Laluraj CM, Martin GD, Srinivas K, Venugopal P (2006) Environmental analysis of heavy metal deposition in a flow-restricted tropical estuary and its adjacent shelf. Environ Forensic 7:345-351 
Banerjee K, Senthilkumar B, Purvaja R, Ramesh R (2012) Sedimentation and trace metal distribution in selected locations of Sundarbans mangroves and Hooghly estuary, northeast coast of India. Environ Geochem Health 34:27-42

Banu Z, Chowdhury MSA, Hossain MD, Nakagami K (2013) Contamination and ecological risk assessment of heavy metal in the sediment of Turag River, Bangladesh: an index analysis approach. Journal Water Resources and Protection 5:239-248

Barbieri JM (2016) The importance of enrichment factor (EF) and geoaccumulation index (Igeo) to evaluate the soil contamination. J Geol Geophys 5:1-4

Battaglini P, Andreozzi G, Antonucci R, Arcamone N, De Girolamo P, Ferrara L, Gargiulo G (1993) The effects of cadmium on the gill of the goldfish Carassius auratus. L. Metal uptake and histochemical changes. Comp Biochem Physiol 104C:239-247

Bhuyan MS, Abu Bakar M, Un Nabi MR, Senapathi V, Chung SY, Islam MS (2019) Monitoring and assessment of heavy metal contamination in surface water and sediment of the Old Brahmaputra River, Bangladesh. Appl Water Sci 9:125

Bryan GW, Langston WJ (1992) Bioavailability, accumulation and effects of heavy metals in sediments with special reference to United Kingdom estuaries: a review. Environ Pollut 76:89-131

Buccolieri A, Buccolieri G, Cardellicchio N, Atti AD, Leo AD, Maci A (2006) United States heavy metals in marine sediments of Taranto Gulf (Ionian Sea, Southern Italy). Mar Chem 99:227-235

Carthew KD, Taylor MP, Drysdale RN (2003) Are current models of tufa sedimentary environments applicable to tropical systems? A case study from the Gregory River. Sediment Geol 162:199-221

Central Pollution Control Board (CPCB) (2013) Pollution assessment: River Ganga, July 2013. Ministry of Environment and Forests, Govt. of India

Chakraborty D, Gupta TK (2003) Rapid estimation of major wastewater discharges to river Hooghly between the stretches of Palta to Dhankhetikhal. West Bengal Pollution Control Board:1-19

Chakraborty D, Singh SK, Rahman MM, Dutta RN, Mukherjee SC, Pati S, Kar PB (2018) Groundwater arsenic contamination in the Ganga river basin: a future health danger. Int J Environ Res Public Health 15:180-199

Chatterjee M, Silva Filho EV, Sarkar SK, Sella SM, Bhattacharya A, Satpathy KK (2007) Distribution and possible source of trace elements in the sediment cores of a tropical macrotidal estuary and their ecotoxicological significance. Environ Int 33:346-356

Costa LDF, Mirlean N, Wasserman JC, Wallner-Kersanach M (2016) Variability of labile metals in estuarine sediments in areas under the influence of antifouling paints southern Brazil. Environ Earth Sci 75:580

Davaulter V, Rognerud S (2001) Heavy metal pollution in sediments of the Pasvik River drainage. Chemosphere 42:9-18

Devanesan E, Gandhi MS, Selvapandiyan M, Senthilkumar G, Rasankar R (2017) Heavy metal and potential ecological risk assessment in sediments collected from Poombuhar to Karaikal coast of Tamilnadu using energy dispersive X-ray fluorescence (EDXRF) technique. Beni-Suef University Journal Basic Applied Science 6:285-292

Dhanakumar S, Murthy KR, Solaraj G, Mohanraj R (2013) Heavy-metal fractionation in surface sediments of the Cauvery River Estuarine Region, southeastern coast of India. Arch Environ Contam Toxicol 65:14-23

Du Laing G, De Vos R, Vandecasteele B, Lesage E, Tack FMG, Verloo MG (2008) Effect of salinity on heavy metal mobility and availability in intertidal sediments of the Scheldt estuary Estuarine. Coastal and Shelf Science 77:589-602

Dutta S, Kole RK, Ghosh S, Nath D, Vass KK (2005) Impact assessment of lead on water quality of river Ganga in West Bengal, India. Bull Environ Contam Toxicol 75:1012-1019

Folk RL, Ward WC (1957) Brazos River bar: a study in the significance of grain size parameters. J Sediment Petrol 27:3-26
Ghosh BB, Bagchi MM, De DK (1983) Some observations on the status of pollution in the Hooghly estuary (West Bengal) with reference to heavy metals deposited through industrial wastes. Journal Inland Fisheries Society of India 15:44-53

Hakanson L (1980) Ecological risk index for aquatic pollution control, a sedimentological approach. Water Res 14:975-1001

Hassan M, Mirza ATM, Rahman T, Saha B, Kamal AKI (2015) Status of heavy metals in water and sediment of the Meghna River, Bangladesh. Am J Environ Sci 11:427-439

Helmke PA (1999) Chemistry of cadmium in soil solution. In: McLaughlin MJ, Singh BR (eds) Cadmium in Soils and Plants. Kluwer Academic Publishers, Dordrecht, The Netherlands, pp 39-64

Hu B, Li J, Zhao J, Yang J, Bai F, Dou Y (2013) Heavy metal in surface sediments of the Liaodong Bay, Bohai Sea: distribution, contamination, and sources. Environ Monit Assess 185:5071-5083

Islam F, Rahman M, Khan SSA, Ahmed B, Bakar A, Halder M (2013) Heavy metals in water, sediment and some fishes of Karnofuly River, Bangladesh. Pollut Res 32:715-721

Islam MS, Ahmed MK, Raknuzzaman M, Habibullah-Al-Mamun M, Masunaga S (2015) Assessment of trace metals in fish species of urban rivers in Bangladesh and health implications. Environ Toxicol Pharmacol 39:347-357

Islam SMD, Bhuiyan MAH, Rume T, Mohinuzzaman M (2016) Assessing heavy metal contamination in the bottom sediments of Shitalakhya River, Bangladesh; using pollution evaluation indices and geo-spatial analysis. Pollution. 2:299-312

Janaki-Raman D, Jonathan MP, Srinivasalu S, Armstrong-Altrin JS, Mohan SP, Ram-Mohan V (2007) Trace metal enrichments in core sediments in Muthupet mangroves, SE coast of India: application of acid leachable technique. Environ Pollut 145:245-257

Jiang M, Zeng G, Zhang C, Ma X, Chen M, Zhang J, Lu L, Yu Q, Hu L, Liu L (2013) Assessment of heavy metal contamination in the surrounding soils and surface sediments in Xiawangang River, Ingshuitang District. Plos One Journal 8:e71176. https://doi.org/ 10.1371/journal.pone.0071176

Jonathan MP, Ram Mohan V (2003) Heavy metals in sediments of the inner shelf off the Gulf of Mannar, South East Coast of India. Mar Pollut Bull 46:263-268

Jonathan MP, Sarkar SK, Roy PD, Alam MA, Chatterjee M, Bhattacharya BD (2010) Acid leachable trace metals in sediment cores from Sunderban Mangrove Wetland, India: an approach towards regular monitoring. Ecotoxicology 19:405-418

Kar D, Sur P, Mandai SK, Saha T, Kole RK (2008) Assessment of heavy metal pollution in surface water. Int J Environ Sci Technol 5:119-124

Kerolli-Mustafa M, Fajković H, Rončević S, Ćurković L (2015) Assessment of metals risks from different depths of jarosite tailing waste of Trepça Zinc Industry, Kosovo based on BCR procedure. J Geochem Explor 148:161-168

Krupadam RJ, Ahuja R, Wate SR (2007) Heavy metal binding fractions in the sediments of the Godavari estuary, East Coast of India. Environ Model Assess 12:145-155

Lebart L, Morineau A, Warwick KM (1984) Multivariate descriptive statistical analysis. John Wiley \& Sons, New York

Liang J, Liu J, Xu G, Chen B (2020) Grain-size characteristics and net transport patterns of surficial sediments in the Zhejiang nearshore area, East China Sea. Ocean 65:12-22

Millward GE, Liu YP (2003) Modelling metal desorption kinetics in estuaries. Sci Total Environ 314-316:613-623

Mohiuddin KM, Alam MM, Ahmed I, Chowdhury AK (2015) Heavy metal pollution load in sediment samples of the Buriganga river in Bangladesh. Journal Bangladesh Agricultural University 13:229 238

Mondal P, Mendes RA, Jonathan MP, Biswas JK, Murugan K, Sarkar SK (2018a) Seasonal assessment of trace element contamination in intertidal sediments of the meso-macrotidal Hooghly (Ganges) river 
estuary with a note on mercury speciation. Mar Pollut Bull 127:117130

Mondal P, Reichelt-Brushett AJ, Jonathan MP, Sujitha SB, Sarkar SK (2018b) Pollution evaluation of total and acid-leachable trace elements in surface sediments of Hooghly river estuary and Sundarban mangrove wetland (India). Environ Sci Pollut Res 25:5681-5699

Mondal P, Schintu M, Marras B, Bettoschi A, Marrucci A, Sarkar SK, Chowdhury R, Jonathan MP, Biswas JK (2020) Geochemical fractionation and risk assessment of trace elements in sediments from tide-dominated Hooghly (Ganges) river estuary, India. Chem Geol 532:119373. https://doi.org/10.1016/j.chemgeo.2019.119373

Mukherjee M, Ghosh A, Maitra S (2015) Isolation and characterization of nickel and cadmium accumulating bacterial isolates from Mystus cavasius and Glossogobius giuris of river Hooghly. Int J Curr Microbiol App Sci 4:726-773

Muller G (1969) Index of geo-accumulation in the sediments of the Rhine River. Geo-Journal 2:108-118

Müller G (1981) Die Schwermetallbelstung der sedimente des Neckars und seiner Nebenflusse: eine Bestandsaufnahme. Chemicher Zeitung 105:157-164

Muthu Raj S, Jayaprakash M (2008) Distribution and enrichment of trace metals in marine sediments of Bay of Bengal, off Ennore, south-east coast of India. Environ Geol 56:207-217

NACER (2020) Livelihood and health challenges of riverine communities of the river Ganga, vol 103. Anil K. Sharma, New Delhi, India

Nemr AE, Khaled A, Sikaily AE (2006) Distribution and statistical analysis of leachable and total heavy metals in the sediments of the Suez Gulf. Environ Monit Assess 118:89-116

Paalman MAA, van der Weijden CH, Loch JPG (1994) Sorption of cadmium on suspended matter under estuarine conditions: competition and complexation with major seawater ions. Water Air Soil Pollut 73:49-60

Paul AC (2017) Research on heavy metal pollution of river Ganga: a review. Ann Agric Sci 15:78-286

Paul AC, Pillai KC (1990) Leachability of radium from fertilizer and monazite process wastes. In: The Environmental Behaviour of Radium. IAEA Technical Report Series No.310, IAEA, Vienna, pp 83-95

Paul D, Sinha SN (2013) Assessment of various heavy metals in surface water of polluted sites in the lower stretch of river Ganga, West Bengal: a study for ecological impact. Discovery Nature 6:8-13

Rahman MS, Saha N, Molla AH (2014) Potential ecological risk assessment of heavy metal contamination in sediment and water body around Dhaka export processing zone, Bangladesh. Environ Earth Sci 71:2293-2308

Rakshit D, Biswas SN, Sarkar SK, Bhattacharya BD, Godhantaraman N, Satpathy KK (2014) Seasonal variations in species composition, abundance, biomass and production rate of tintinnids (Ciliata: Protozoa) along the Hooghly (Ganges) river estuary, India: a multivariate approach. Environ Monit Assess 186:3063-3078

Ramesh R, Ramanathan AL, James RA, Subramanian V, Jacobsen SB, Holland HD (1999) Rare earth elements and heavy metal distribution in estuarine sediments of east coast of India. Hydrobiology 397: 89-99

Ravichandran M, Baskaran M, Santschi PH, Bianchi T (1995) History of trace metal pollution in Sabine-Neches Estuary, Beaumont, Texas. Environ Sci Technol 29:1495-1503

Ray R, Rixen T, Baum A, Malik A, Gleixner G, Jana TK (2015) Distribution, sources and biogeochemistry of organic matter in a mangrove dominated estuarine system (Indian Sundarbans) during the pre-monsoon. Estuar Coast Shelf Sci 167:404-413

Rokade MA (2009) Heavy metal burden in coastal marine sediments of north west coast of India related to pollution. University of Mumbai

Sarkar SK, Bilinski SF, Bhattacharya A, Saha M, Bilinski H (2004) Levels of elements in the surficial estuarine sediments of the Hugli river, northeast India and their environmental implications. Environ Int 30:1089-1098

Sarkar SK, Mondal P, Biswas JK, Kwon EE, Ok YS, Rinklebe J (2017) Trace elements in surface sediments of the Hooghly (Ganges) estuary: distribution and contamination risk assessment. Environ Geochem Health 39:1245-1258

Sekabira K, Oryem-Origa H, Mutumba GM (2010) Assessment of heavy metal pollution in the urban stream sediments and its tributaries. Int $\mathrm{J}$ Environ Sci Technol 7:435-446. https://doi.org/10.1007/ BF03326153

Sharma SK, Subramanian V (2010) Source and distribution of trace metals and nutrients in Narmada and Tapti river basins, India. Environ Earth Sci 61:1337-1352

Subba Rao M (1960) Organic matter in the marine sediments off east coast of India. Bull Am Assoc Pet Geol 44:1705-1713

Sunil Kumar R (1996) Distribution of organic carbon in the sediments of Cochin mangroves, south west coast of India. Indian Journal Marine Science 25:274-276

Taylor SR, McLennan SM (1985) The continental crust: its composition and evolution. Blackwell, Oxford

Tomlinson DL, Wilson JC, Harris CR, Jeffrey DW (1980) Problems in the assessment of heavy-metal levels in estuaries and the formation of a pollution index. Helgoländer Meeresun 33:566-575

Trifuoggi M, Donadio C, Mangoni O, Ferrara L, Bolinesi F, Nastro RA, Stanislao C, Toscanesi M, Di Natale G, Arienzo M (2017) Distribution and enrichment of trace metals in surface marine sediments in the Gulf of Pozzuoli and off the coast of the brownfield metallurgical site of Ilva of Bagnoli (Campania, Italy). Mar Pollut Bull 124:502-511

UNEP (1996) State of Marine and Coastal Environment in the Mediterranean Region MAP Technical Reports Series 100, Athens

Vaezi AR, Karbassi AR, Kokabi-Habibzadeh S, Heidari M, Valikhani Samani AR (2016) Heavy metal contamination and risk assessment in the riverine sediment. Indian. J Mar Sci 45:1017-1023

West Bengal Pollution Control Board WBPCB (2009) A State of Environment Report. Water Resource and its Quality in West Bengal, Kolkata, 352p

Yin H, Tan N, Liu C, Wang J, Liang X, Qu M, Feng X, Qiu G, Tan W, Liu F (2016) The associations of heavy metals with crystalline iron oxides in the polluted soils around the mining areas in Guangdong Province, China. Chemosphere 161:181-189

Zhang J, Liu CL (2002) Riverine composition and estuarine geochemistry of particulate metals in China-weathering features, anthropogenic impact and chemical fluxes. Estuar Coast Shelf Sci 54:1051-1070

Zhang Y, Guo F, Meng W, Wang XQ (2009) Water quality assessment and source identification of Daliao river basin using multivariate statistical methods. Environ Monit Assess 152:105-121

Publisher's note Springer Nature remains neutral with regard to jurisdictional claims in published maps and institutional affiliations. 